\title{
ASSESSMENT OF Candida SPP. PROLIFERATION IN OCCLUSAL AND PALATAL SPLINTS
}

\author{
AVALIAÇÃO DA PROLIFERAÇÃO Candida SPP. EM PLACAS OCLUSAIS E \\ PALATAIS
}

\section{Sigmar de Mello RODE; ${ }^{1}$ Renata Pilli JÓIAS²; Jonatas Rafael de OLIVEIRA ${ }^{3}$; Maria Fernanda MATTOS*3 Antônio Olavo Cardoso JORGE³; Michelle Perreluppi SILVA³; Ellen Cristina Libonati SEIXAS ${ }^{4}$}

1. Departamento de matérias dentários e prótese, UNESP, São José dos Campos, SP, Brasil; 2. Departamento de ortodontia, UMESP, São Bernardo do Campo, SBC, Brasil; 3. Departamento de microbiologia e biopatologia oral, UNESP, São José dos Campos, SP, Brasil; 4. Departamento de ortodontia, UNICID, São Paulo, SP, Brasil. ellen.sxs@ hotmail.com

\begin{abstract}
Candida species inhabit the oral cavity of all individuals who wear complete denture and whose material is the same as that used in splints. Assess the growth of $C$. albicans in occlusal and palatal splints used for treatment of TMD so that the potential risks of oral microbiota can be assessed. The growth of Candida spp. was assessed in the saliva of 27 individuals wearing splints for treatment of TMD. They were divided into two groups: G1 ( $\mathrm{n}=14$ ), individuals wearing occlusal splint; and G2 $(n=13)$, individuals wearing palatal splint. Saliva samples were collected during placement of the splints (T1) and after 4 months (T2), being stored in PBS (10 mL) after 60-second rinses. It was observed that patients wearing occlusal splints (G1) had an increase of $0.648 \mathrm{CFU} / \mathrm{mL}$ (Log 10), with statistically significant differences $(P=0.043)$ for $C$. albicans $(42.33 \%)$, C. glabrata $(5.52 \%)$, C. krusei $(41.72 \%)$ and $C$. tropicalis $(10.43 \%)$. In the group of patients wearing palatal splints (G2), there was a decrease of $0.101 \mathrm{CFU} / \mathrm{mL}$ (Log 10), was observed with $(P=0.964)$ only the presence of $C$. albicans. The results suggest that growth of Candida species was greater in patients wearing occlusal splints compared to those wearing palatal ones as the presence of different yeast species was found in the former.
\end{abstract}

KEYWORDS: Candida. Colony-forming units. Muscle relaxant splints

\section{INTRODUCTION}

Temporo-mandibular joint dysfunction (TMD) is a complex set of symptoms involving structures surrounding the temporo-mandibular joint (TMJ) and masticatory muscle, or both (DE LEEUW, 2008), in association with pain (BENOLIEL; SHARAV, 2008). TMD can be classified as muscular, articular or mixed (DWORKIN, 2011), being the most prevalent type of chronic orofacial pain and the third most prevalent type of chronic pain, only behind common headaches and backaches. (DWORKIN, 2011). Although several types of treatment have been suggested in the literature (MINAGI et al., 2001; TSUKIYAMA et al., 2001), such as occlusal splint therapy, drug therapy, surgical therapy, occlusal adjustment, physical therapy and psychological counselling, it is clear that the use of occlusal splints is consecrated for treating muscle TMD. However, palatal splints are an alternative to the occlusal ones as the former have the distinction to adjust to the hard palate without interfering occlusion semiadjustable articulator mounting or splint adjustment (MINAGI et al., 2001; HASEGAWA et al., 2007). Although the patients are guided to wear the splints for several hours consecutively on a daily basis, it is important to emphasise that these dental appliances are colonised by pathogens which have the potential to cause risks.

Candida yeasts are micro-organisms which are widely spread in the nature, with some species living as saprophytes or parasites in human beings and other animal species. Associated with human beings and other warm-blooded animals, Candida albicans usually lives in the oropharynx, mouth, skin folds, bronchial secretion, vagina, urine and faeces. The occurrence of this species in water and soil is relatively rare and is related to the contamination of these environments by human beings and animals (LIM et al., 2012).

Considered the most prevalent pathogenic fungus in humans, $C$. albicans can be commonly isolated from the oral cavity of adults and children, often resulting in systemic or superficial infections (THEIN et al., 2006; RAMAGE et al., 2006), such as candidiasis (RAMAGE et al., 2007; VIDAL et al., 2011), and even in death in the cases of immunocompromised individuals (LIM et al., 2012). Because $C$. albicans is a component of the oral microbiota (WILLIAMS; LEWIS, 2011), this microorganism can be easily isolated from approximately $60 \%$ of healthy individuals (PEREIRA et al., 2008; JAROSZ et al., 2009). 
Among the most important virulence factors of Candid spp., one can observe that this microorganism has the ability to adhere to surfaces by producing filamentous growth and releasing hydrolytic enzymes capable of damaging the host cells, in addition to forming biofilms, thus reducing the susceptibility to antimicrobial agents (WILLIAMS; LEWIS, 2011; SILVA et al., 2012). In general, tongue, oral mucosa, tooth surface, biofilm and saliva are areas of preference for colonisation by this micro-organism. Local factors such as poor oral hygiene, poorly-adjusted dentures, decreased salivary flow, presence of caries as well as systemic factors such as nutritional deficiency, malignant tumours, use of broad-spectrum antibiotics, smoking, diabetes, salivary gland disorders and immune response deficiency can favour the proliferation of Candida species in the oral cavity (PEREIRA et al., 2008;ROWAN et al., 2009). Some cases of candidiasis are associated with several implantable medical devices and appliances made of acrylic resin (NIKAWA et al., 1994; PEREIRA et al., 2007), such as dental prostheses and others, whose surfaces are susceptible to biofilm formation and which, in turn, tend to impede the immune response and other defence mechanisms (RIZK; FALKLER; MEILLER, 2004; SAMARANAYAKE; WU; SAMARANAYAKE; SO M; YUEN, 1994). Candida species are found in the oral cavity of $60-100 \%$ of the individuals wearing complete denture (DAĞISTAN; AKTAS; CAGLAYAN; AYYILDIZ; BILGE, 2009), whose material is the same as that used in the manufacture of splints. Therefore, as there is a shortage of studies on the colonisation of these plates by Candida



Figure 1. Occlusal splint. species, it is important and necessary to assess the growth of this micro-organism in splints. The objective of the present study was to assess the growth of Candida species in occlusal and palatal splints used for treatment of TMD in order to verify potential risks to the oral microbiota.

\section{MATERIAL AND METHODs}

An Ethics Committee approved this study (CAAE: 14385213.2.0000.0077).

\section{Volunteers}

The volunteers of this study comprised a convenience sample, as we have assessed 14 occlusal (G1) (Figure 1) and 13 palatal splints (G2) (Figure 2) in individuals undergoing treatment for TMD at the Centre for Occlusion and Temporomandibular Joint Treatment $(C O A T)$ of the Institute of Sciences and Technology, São José dos Campos Dental School (UNESP). For inclusion, patients had to be between 18 and 44 years old, have myofascial pain and have complete permanent dentition up to second molars. Those excluded were individuals in perimenopause; those with complete, uni- or bi-maxillary, or removable dentures; those with uni- or bi-lateral lack of posterior support; those who made continual use of any drugs or medication.

The patients were guided to wear the splints during sleeping for 8-10 hours for 4 months. They were also guided to clean their splints by using dentifrice and toothbrush only after removing them in the morning.
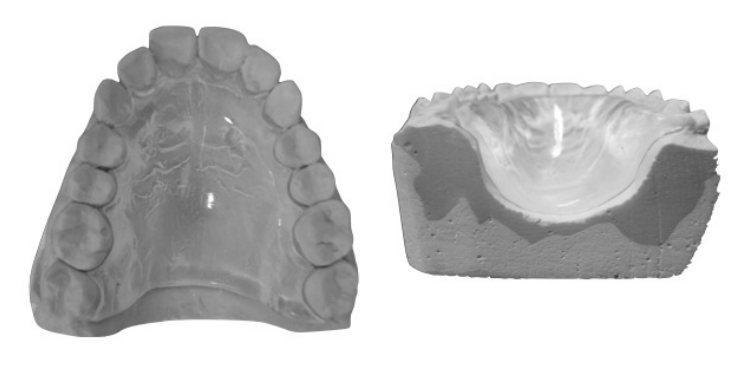

Figure 2. Palatal splint in oclusal and posterior view. 
Microbial samples were collected twice, that is, immediately before placement of the splint (T1) and after four months of use (T2) according to protocol already validated in the literature (24).

\section{Sample Collection}

The patient rinsed the mouth with $10 \mathrm{~mL}$ of phosphate buffered saline solution for 60 seconds before spitting out the rinse material into the same container.

\section{Centrifugation}

The samples underwent centrifugation at $8,000 \mathrm{xg}$ for 10 minutes and the supernatant was disregarded. The resulting pellet was resuspended in $2.5 \mathrm{~mL}$ of PBS solution and homogenised for 30 seconds by means of a shaker.

\section{Culture}

One-hundred $\mathrm{mL}$ of the Falcon tube content were seeded onto CHROMagar Candida agar plates and the inoculums were spread out by using a Drigalski spatula. Next, the agar plates were incubated at $37^{\circ} \mathrm{C}$ for 48 hours.

\section{Bacterial Counting}

Colony-forming units per millimeter (CFUs $/ \mathrm{mL}$ ) were counted per agar plate. Presumptive identification of Candida species was performed by observing the morphology and colour of the colonies.

\section{Splints Protocol of use}

All the patients were given the same instructions regarding the use and cleaning of the splints. They were also guided to wear the splint during sleeping at night and to keep it in water when not in use in order to avoid dimensional changes.

It was also recommended that the splints should be thoroughly cleaned by using toothbrush and fluoride dentifrice.

\section{Statistical Analysis}

For statistical analysis, we used the GraphPad Prism 5 software. For verification of the adherence to normal distribution, the mean and standard deviation (SD) of the results obtained from each experimental group were analyzed with the Shapiro-Wilk test. After analysis it was verified that the data does not have the normal distribution, and then nonparametric Wilcoxon and Mann-Whitney tests were used. In all tests, a 5\% significance level was used.

\section{RESULTS}

The patients wearing occlusal splints (Group1) had an increase of $0.648 \mathrm{CFU} / \mathrm{mL}$ (log $10)$, which was statistically significant $(P=0.043)$ in the comparison between the mean values at $\mathrm{T} 1$ and $\mathrm{T} 2$ (i.e. $0.473 \mathrm{CFU} / \mathrm{mL}$ and $1.121 \mathrm{CFU} / \mathrm{mL}$ (Figure 1), respectively for C. albicans (42.33\%), $C$. glabrata (5.52\%), C. krusei (41.72\%) and $C$. tropicalis $(10.43 \%)$ (Table 1). In the palatal splints group (Group2), a decrease of $0.101 \mathrm{CFU} / \mathrm{mL}(P=$ 0.964 ) was observed between the mean values at $\mathrm{T} 1$ and $\mathrm{T} 2$ (i.e. $0.359 \mathrm{CFU} / \mathrm{mL}$ and $0.258 \mathrm{CFU} / \mathrm{mL}$, respectively) for $C$. albicans only. In comparison between intragroups (Wilcoxon test) the results observed were $\mathrm{T}=66$ with statistically significant $\mathrm{P}=0.0038$ for $\mathrm{G} 1$ and $\mathrm{T}=3$ and $\mathrm{P}=0.5$ for $\mathrm{G} 2$.

Figure 1. Mean and standard deviation of CFU/mL (Log 10) obtained in occlusal (G1) and palatal splints (G2) immediately before placement of the splint (T1) and after four months of use (T2).

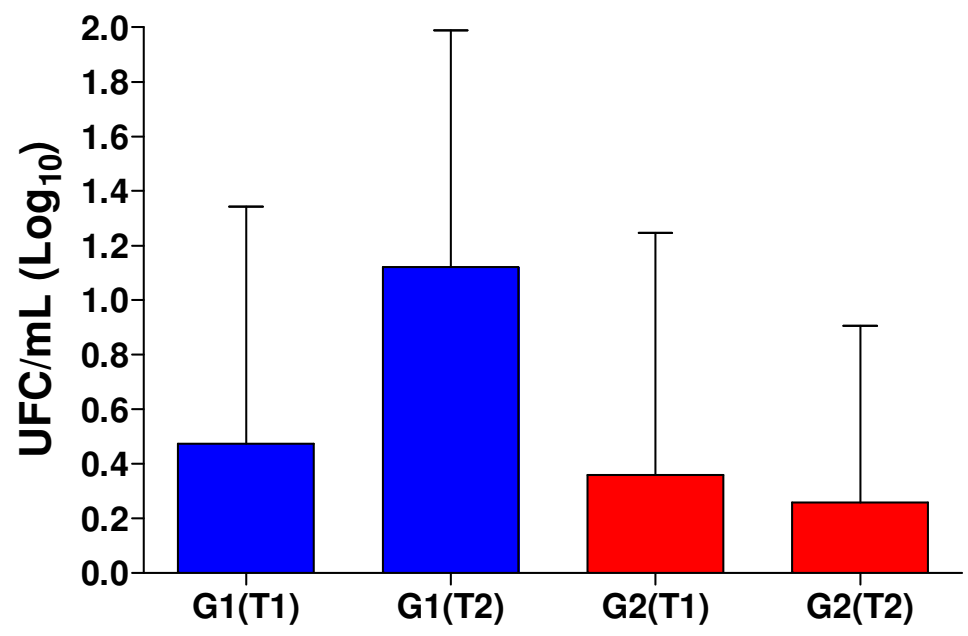


Table 1. Percentage of microorganisms found in the splints.

\section{Candida species}

occlusal (G1)

palatal splints $(\mathrm{G} 2)$

$42.33 \%$ C. albicans

$5.52 \%$ C. glabrata

$41.72 \%$ C. krusei

$100 \%$ C. albicans

$10.43 \%$ C. tropicalis

\section{DISCUSSION}

C. albicans and several other Candidarelated species are commensal micro-organisms found in the oral cavity (PIERCE et al., 2017). Approximately $60 \%$ of healthy adults and 26-65\% of healthy children can present Candida species with no signs or symptoms of candidiasis (KADIR; GÜMRÜ; UYGUN, 2007; MEGHA; NOBILE, 2016). The balance between host and Candida yeasts can be modified under several systemic and oral conditions, resulting in the proliferation of Candida species in the mouth and lesions consequently (KADIR; GÜMRÜ; UYGUN, 2007; KADIR et al., 2002). Candida species develop specific virulence mechanisms enabling these micro-organisms to colonise the host's epithelial cells and invade the deepest ones, thus affecting the host's defence (KADIR; GÜMRÜ; UYGUN, 2007).

The literature shows that when certain types of dental materials are exposed to oral milieu, they are immediately covered by salivary components and then by micro-organisms in the oral cavity. Oral biofilms can contribute to the occurrence of diseases, such as caries, periodontitis or prosthetic stomatitis (HAHNEL et al., 2009). Candida yeast has been identified as a major agent of these infections (RAMAGE; MARTINEZ; LOPEZ, 2006; HAHNEL; ROSENTRITT; HANDEL; BÜRGERS, 2009; OLIVEIRA et al., 2007), also being found to be adhered to numerous dental materials such as acrylic resins (e.g. prosthesis) and silicone (e.g. overlay), as reported by in vitro and in vivo studies (NIKAWA et al., 1994; PEREIRA et al., 2007; RADFORD; CHALLACOMBE; WALTER, 1999; NEVZATOĞLU et al., 2007).

As the present study has assessed the growth of Candida species in a convenience sample of patients wearing splints at COAT, maybe the results shouldn't be generalizable to all Brazialian individuals with TMD. However, as the inclusion and exclusion criteria guarantee no usage of medications or drugs even presence of any illness that could interfere in the oral microbiota, our results are important to identify the amount of Candida associated to the use of mouth splints and according to the results obtained, a greater microbial growth was observed in occlusal ones. A number of factors may contribute to both growth and replication of micro-organisms, and possibly one of the main factors is the habitat formation, which would enable conditions for development and survival of Candida species.

Candida yeasts can grow as a biofilm on several human tissues as well as on several types of biomaterials, including acrylic prostheses, thus causing morbidity (MEGHA; NOBILE, 2016; PIERCE et al., 2017). Oral candidiasis, in association with biological materials, is the most common fungal infection in wearers of dental prostheses (WILLIAMS; LEWIS, 2011).

Based on our results, we have observed the presence of different Candida species in the oral cavity of patients wearing occlusal splints, whereas C. albicans was predominant in individuals wearing palatal splints. As Candida species are oral commensal micro-organisms present in $50-60 \%$ of the population, they can be transitory or permanent (KADIR et al., 2002). C. albicans are the most opportunistic pathogenic fungus.

Factors determining the virulence of Candida species can be unchained by local environmental stimuli (RAMACHANDRA et al., 2014), including $\mathrm{pH}$, nutritional availability and gaseous compensation (KADIR; GÜMRÜ; UYGUN, 2007). In addition, studies have already demonstrated that the properties of colonised surfaces (e.g. surface roughness and load) and the composition of salivary pellicle increase the development of biofilm (CUSTODIO et al., 2015; DA SILVA et al., 2014).

Earlier studies showed that the surface properties of bio-materials play a significant role in the development of micro-organisms and formation 
of biofilm (DA SILVA et al., 2014), mainly due to the increased microbial colonisation on rough surfaces (PEREIRA et al., 2007; DA SILVA et al., 2014).

Surface roughness is extremely important during the adhesion phase of $C$. albicans (HAHNEL; ROSENTRITT; HANDEL; BÜRGERS, 2009; RADFORD; CHALLACOMBE; WALTER, 1999). Some in vitro studies have concluded that surface roughness accounts for the $C$. albicans adhesion to dental bio-materials (PEREIRA et al., 2007). These studies on dental development and protein plaques have similarities regarding biofilm formation in different types of surfaces in the oral cavity. Rough surfaces tend to promote in vivo biofilm formation as these surfaces are more likely to have micro-organisms. In addition, rough surfaces provide larger areas and a safer environment for development of micro-organisms (RADFORD; CHALLACOMBE; WALTER, 1999).

Adhesion of micro-organisms to the splints may also be related to salivary flow, both reducing the volume of saliva and hindering it to reach areas of the oral cavity covered by the splint. Such a finding was also observed in the study conducted by BARBEAU et al. (2003), who assessed a case of prosthetic stomatitis and found evidence of reduced salivary flow, including lack of saliva on acrylic surface, which contributes to formation and accumulation of biofilm (WILLIAMS et al., 2013).

Although the precise mechanisms by which the adhesion of Candida species to acrylic surfaces occurs are not known, many factors affecting this process have already been described, such as surface roughness, salivary pellicle, and hydrophobic and electrostatic interactions (RADFORD; CHALLACOMBE; WALTER, 1999).

SANCHEZ et al. (2013) reported the presence of other Candida species in the oral cavity by means of a longitudinal study to quantify biofilms in oral clinical isolates from adult individuals presenting local and systemic predisposing factors for candidiasis. A total of 69 Candida yeasts isolated from 63 Mexican patients were evaluated. These isolated (39 C. albicans, 15 Candida tropicalis, 7 Candida glabrata, 4 C. krusei, 1 Candida lusitaniae, 1 Candida kefyr, 1 Candida Guilliermondii and 1 Candida pulcherrima) were obtained from two clinical origins: $62.3 \%(n=43)$ from oral mucosa of fully or partially edentulous individuals and $37.7 \%(n=26)$ from oral mucosa of diabetic individuals. Standard strains of Candida were used as controls in each experiment. The authors concluded that biofilm formation depends on both Candida species and clinical origin, reporting that oral isolates of $C$. glabrata are strong producers of biofilm, whereas $C$. albicans and $C$. tropicalis are moderate ones. However, $C$. albicans was the most common species.

These results corroborate our study regarding the diversity of other Candida species, despite the fact that $C$. albicans prevailed.

THEIN et al. (2007) evaluated the interactions between C. albicans and C. krusei in acrylic prostheses, concluding that quantitative and qualitative characteristics of a given Candida species can change the other's physiology during co-habitation in the biofilm. In addition, human saliva can modulate this process depending on the nature and number of species in the habitat. Therefore, competing interactions between fungal species are important in the formation of biofilms on acrylic surfaces, with human saliva modulating this process.

ARIAS et al. (2009) described the isolation of $C$. dubliniensis from patients with prosthetic stomatitis and compared the presence of yeasts in the oral cavity of prosthesis wearers, with the authors reporting the predominance of $C$. albicans other than non-albicans species such as $C$. tropicalis, C. guilliermondii, C. glabrata and $C$. parapsilosis. These results are in accordance with ours regarding patients wearing occlusal splints, demonstrating that $C$. albicans was present in the oral cavity in 100 percent of the cases.

In view of the impossibility to treat fungal infection by using antifungal therapy, we have emphasised the importance of treatment methods for reducing the initial fungal adhesion since colonisation and consequently the $C$. albicans adhesion to oral surfaces, including mucosa and prosthetic surfaces (VERRAN; MARYAN, 1997; NIKAWA et al., 1997; ZAMPERINI et al., 2010; PIERCE et al., 2017).

Other important factor in determining the microbial colonisation of the oral cavity in patients wearing splints was the hygienisation of both appliance and mouth, that is, frequency of tooth brushing and cleaning of the splints according to the guidance received.

In sum, it is impossible to separate the set of factors which determine the conditions for microbial development, growth and colonisation of the oral cavity. Saliva composition, salivary flow rate, predisposition to caries, immune response, hygiene habits (i.e. manner and frequency of tooth brushing), time length of the splint within the mouth, cleaning of the splint, and type of material and structure of the splint are factors which may predispose the patient to a greater number of micro-organisms in 
the oral cavity, thus allowing for the development of candidiasis. Therefore, our results are consistent with the findings reported elsewhere, but not all patients responded to treatment in a similar way.

\section{CONCLUSION}

Patients wearing occlusal splints showed a greater growth of Candida species compared to those wearing palatal ones as different species of yeasts were observed.

RESUMO: Espécies de Candida habitam a cavidade oral de 60-100\% de indivíduos usuários de prótese total, cujo material é o mesmo utilizado em placas miorrelaxante. Avaliar o crescimento de C. albicans. em placas relaxantes musculares oclusais e palatais, usadas para o tratamento de DTM, na intenção de verificar riscos em potencial à microbiota bucal. Avaliou-se o crescimento de Candida spp. na saliva de 27 indivíduos, usuários de placa miorrelaxante, em tratamento para DTM no ICT-UNESP. Os indivíduos foram divididos em dois grupos: G1(n=14) - placa com recobrimento oclusal; e G2 (n=13) - sem recobrimento. As coletas foram com PBS (10mL), em bochechos por 60seg, na instalação das placas (T1) e após 4 meses (T2). Observou-se que pacientes usuários da placa miorrelaxante com recobrimento oclusal (grupo G1) apresentaram aumento de 0,648 UFC/mL (Log10) com diferença estatisticamente significante $(\mathrm{p}=0,043)$ analisando-se $42,33 \%$ C. albicans, 5,52\% C. glabrata, $41,72 \%$ C. krusei e $10,43 \%$ C. tropicalis. No grupo de pacientes que utilizaram a placa sem recobrimento (grupo G2), observou-se diminuição de $0,101 \mathrm{UFC} / \mathrm{mL}$ $(\log 10)$ com $(\mathrm{p}=0,954)$ apresentando apenas $C$. albicans. Os resultados sugerem que os pacientes que fizeram uso de placa miorrelaxante com recobrimento oclusal apresentaram maior crescimento de Candida spp. em relação aos usuários de placa sem recobrimento, verificando-se a presença de diferentes espécies da levedura.

PALAVRA- CHAVE: Candida. Contagem de Colônia Microbiana. Placas Miorrelaxantes.

\section{REFERENCES}

BARBEAU J, SÉGUIN J, GOULET J. P, DE KONINCK L, AVON SL, LALONDE B, et al. Reassessing the presence of Candida albicans in denture-related stomatitis. Oral Surg Oral Med Oral Pathol Oral Radiol Endod, Toronto, v. 95, n. 1, p. 51-9, 2003. http://dx.doi.org/10.1067/moe.2003.44

BENOLIEL R., SHARAV. Y. Masticatory myofascial pain, tension type and chronic daily headache.

Orofacial pain and headache- Elsevier, Amsterdam, v. 12, n. 11, p. 109-128, 2011.

https://doi.org/10.1016/B978-0-7234-3412-2.10007-0

CUSTODIO W., SILVA W. J., PAES LEME A. F., CURY J. A., DEL BEL CURY A. A. Plasma proteins in the acquired denture pellicle enhance substrate surface free energy and Candida albicans phospholipase and proteinase activities. J Investig Clin Dent, Campinas, v. 6, n. 4, p. 273-81, 2015.

https://doi.org/10.1111/jicd.12101

DA SILVA W. J., LEAL C. M., VIU F. C., GONÇALVES L. M., BARBOSA C. M., DEL BEL CURY A. A. Influence of surface free energy of denture base and liner materials on Candida albicans biofilms. J Investig Clin Dent, Piracicaba, v. 6, n. 2, p. 141-6, 2015. https://doi.org/10.1111/jicd.12079

DWORKIN S. F. Orofacial Pain: Prospective Evaluation and Risk Assessment (OPPERA) study. The Journal of Pain, Carolina do Norte, v. 3, n. 3, p. 1-12, 2011.https:// doi.org/10.1016/j.jpain.2011.08.002

DAĞISTAN S., AKTAS A. E, CAGLAYAN F, AYYILDIZ A, BILGE M. Differential diagnosis of dentureinduced stomatitis, Candida, and their variations in patients using complete denture: a clinical and mycological study. Mycoses, Turquia, v. 52, n. 3, p. 266-71, 2009. https://doi.org/10.1111/j.1439-0507.2008.01592.x

DE LEEUW R. Orofacial pain: guidelines for assessment, diagnosis and management, 4th edn. The American Academy of Orofacial Pain, Quintessence, New Malden, v. 31, n. 2, p. 216-217, 2009. 
HAHNEL S, ROSENTRITT M, HANDEL G, BÜRGERS R. In vitro evaluation of artificial ageing on surface properties and early Candida albicans adhesion to prosthetic resins. J Mater Sci Mater Med, Germany, v. 20, n. 1, p. 249-55, 2009. https://doi.org/10.1007/s10856-008-3570-7

HASEGAWA K. , OKAMOTO M., NISHIGAWA G., OKI K, MINAGI S. The design of non-occlusal intraoral appliances on hard palate and their effect on masseter muscle activity during sleep. Cranio, Okayama, v. 25, n. 1, p. 8-15, 2007. https://dx.doi.org/10.1179/crn.2007.003

JAROSZ L. M., DENG D. M., VAN DER MEI H. C., CRIELAARD W., KROM B. P.. Streptococcus mutans competence-stimulating peptide inhibits Candida albicans hypha formation. Eukaryot Cell, Amsterdam v. 8, n. 11, p. 1658-64, 2009. https://doi.org/10.1128/EC.00070-09

JABRA-RIZK M. A., FALKLER W. A., MEILLER T. F. Fungal biofilms and drug resistance. Emerg Infect Dis, Maryland, v. 10, n. 1, p. 14-9, 2004. https:// doi.org/10.3201/eid1001.030119

KADIR T., GÜMRÜ B., UYGUN-CAN B. Phospholipase activity of Candida albicans isolates from patients with denture stomatitis: the influence of chlorhexidine gluconate on phospholipase production. Arch Oral Biol, 5, Istanbul, v. 52, n. 7, p. 691-6, 2007. https://doi.org/10.1016/j.archoralbio.2006.12.008

KADIR T., PISIRICILER R., AKYÜZ S., YARAT A., EMEKLI N., IPBÜKER A. Mycological and cytological examination of oral candidal carriage in diabetic patients and non-diabetic control subjects: thorough analysis of local aetiologic and systemic factors. J Oral, Istanbul, v. 29, n. 4, p. 452-457, 2002. https://doi.org10.1046/j.1365-2842.2002.00837.x

LIM C. S., ROSLI R., SEOW H. F., CHONG P. P. Candida and invasive candidiasis: back to basics. Eur J Clin Microbiol Infect Dis, Malaysia, v. 31, n. 1, p. 21-31, 2012. https://doi.org/10.1007/s10096-011-1273-3

MARCOS-ARIAS C., VICENTE J. L., SAHAND I. H., EGUIA A., DE-JUAN A., MADARIAGA L. Isolation of Candida dubliniensis in denture stomatitis. Arch Oral Biol. Espanha, v. 54, n. 2, p. 127-31, 2009. https:// doi.org/10.1016/j.archoralbio.2008.09.005

MEGHA G., NOBILE C. Candida albicans biofilms: development, regulation, and molecular. Microbes and Infection, California, v. 18, n. 5, p. 310-321, 2016. https://doi.org/10.1016/j.micinf.2016.01.002

METWALLY L., WALKER M. J., COYLE P. V., HAY R. J., HEDDERWICK S., MCCLOSKEY B. V. Trends in candidemia and antifungal susceptibility in a university hospital in Northern Ireland 2001-2006. J Infect, Irlanda, v. 55, p. 174-8, 2006. https://doi.org/10.1016/j.jinf.2007.04.003

MINAGI S., SHIMAMURA M., SATO T., NATSUAKI N, OHTA M. Effect of a thick palatal appliance on muscular symptoms in craniomandibular disorders: a preliminary study. Cranio, Okayama, v. 19, n. 1, p. 42-7, 2001. https://doi.org/ 10.1080/08869634.2001.11746150

NEVZATOĞLU E. U., OZCAN M., KULAK-OZKAN Y., KADIR T. Adherence of Candida albicans to denture base acrylics and silicone-based resilient liner materials with different surface finishes. Clin Oral Investig, Turquia, v. 11, n. 3, p. 231-6, 2007. https://doi.org/10.1007/s00784-007-0106-3

NIKAWA H., YAMAMOTO T., HAYASHI S., NIKAWA Y., HAMADA T. Growth and/or acid production of Candida albicans on soft lining materials in vitro. J Oral Rehabil, Hiroshima, v. 21, n. 5, p. 585-94, 1994. https://doi.org/10.1111/j.1365-2842.1994.tb01173.x

OLIVEIRA M. A., CARVALHO L. P., GOMES MDE S., BACELLAR O., BARROS T. F., CARVALHO E. M. Microbiological and immunological features of oral candidiasis. Microbiol Immunol, Salvador, v. 51, n. 8, p. 713-9, 2007. htpps://doi.org/ 10.1111/j.1348-0421.2007.tb03960.x 
PEREIRA-CENCI T. , CURY A. A., CENCI M. S., RODRIGUES-GARCIA R. C. In vitro Candida colonization on acrylic resins and denture liners: influence of surface free energy, roughness, saliva, and adhering bacteria. Int J Prosthodont. v. 20, n. 3, p. 308-10, 2007. https://doi.org/ pubmed/17580465

PIERCE C. G., VILA T., ROMO J., MONTELONGO D., MURO G., RAMASUBRAMANIAN A.; LOPEZ R. The Candida Albicans Biofilm Matrix: Composition, Structure and Function. J. Fungi Based, Texas, v. 3, n. 1, p. 1-10, 2017. https://doi.org/ 10.3390 / jof3010014

RAMAGE G., MARTINEZ J. P., LOPEZ-RIBOT J. L. Candida biofilms on implanted biomaterials: a clinically significant problem. FEMS Yeast Res, San Antonio v. 6, n. 9, p. 79-86, 2006. https://doi.org/ 10.1111/j.1567-1364.2006.00117.x

RAMACHANDRA S., LINDE J., BROCK M., GUTHKE R., HUBE B., BRUNKE S. Regulatory networks controlling nitrogen sensing and uptake in Candida albicans. PLoS One, Louisiana v. 20, n. 9, p. 1-11, 2014. hppts://doi.org/10.1371/journal.pone.0092734

RADFORD D. R., CHALLACOMBE S. J., WALTER J. D. Denture plaque and adherence of Candida albicans to denture-base materials in vivo and in vitro. Crit Rev Oral Biol Med, Londres, v. 10, n. 1, p. 99-116, 1999. https://doi.org/ 10.1016/S0300-5712(97)00034-1

ROWAN R., MORAN C., MCCANN M., KAVANAGH K. Use of Galleria mellonella larvae to evaluate the in vivo anti-fungal activity of [Ag2(mal)(phen)3]. Biometals, Kildare, Ireland, v. 3, p. 461-7, 2009.

https://doi.org/10.1007/s10534-008-9182-3

SILVA M. P., CHIBEBE JUNIOR J., JORJÃO A. L., MACHADO A. K., OLIVEIRA L. D., JUNQUEIRA J. C. Influence of artificial saliva in biofilm formation of Candida albicans in vitro. Braz Oral Res, São José dos Campos, v. 26, n. 1, p. 24-8, 2012. http://dx.doi.org/10.1590/S1806-83242012000100005

SAMARANAYAKE Y. H., WU P. C., SAMARANAYAKE L. P., SO M, YUEN K. Y. Adhesion and colonisation of Candida krusei on host surfaces. J Med Microbiol, Hong Kong, v. 41, n. 4, p. 250-8, 1994. https://doi.org/10.1099/00222615-41-4-250

SÁNCHEZ-VARGAS L. O., ESTRADA-BARRAZA D., POZOS-GUILLEN A. J., RIVAS-CACERES R. Biofilm formation by oral clinical isolates of Candida species. Arch Oral Biol, Chihuahua, v. 58, n. 10, p. 1318-26, 2013. https://doi.org/ 10.1016/j.archoralbio.2013.06.006

VERDUYN F., KOELEMAN J., SPANJAARD L., VANDENBROUCKE C., SCHULTZ C., VERBRUGH H, VOS G., TROELSTRA A., MASCINI E., VERWEIJ P., VOSS A. Trends in candidemia and antifungal susceptibility in a university hospital in Northern Ireland 2001-2006. J Infect, Ireland, v. 64, n. 6, p. 236-42, 2006. https://doi.org/ 10.1016/j.jinf.2007.04.003

TSUKIYAMA Y., BABA K., CLARK G. T. An evidence-based assessment of occlusal adjustment as a treatment for temporomandibular disorders. J Prosthet Dent, Los Angeles, v. 86, n. 1, p. 57-66, 2001. htpps://doi.org/10.1067/mpr.2001.115399

THEIN Z. M., SAMARANAYAKE Y. H., SAMARANAYAKE L. P. Effect of oral bacteria on growth and survival of Candida albicans biofilms. Arch Oral Biol, Hong Kong, v. 51, n. 8, p. 672-80, 2006. htpps://doi.org/10.1016/j.archoralbio.2006.02.005

VERRAN J., MARYAN C. J. Retention of Candida albicans on acrylic resin and silicone of different surface topography. J Prosthet Dent, Manchester, v. 77, n. 5, p. 535-9, 1997. https://doi.org/10.1016/S00223913(97)70148-3 
VILLAR-VIDAL M., MARCOS-ARIAS C., ERASO E., QUINDÓS G. Variation in biofilm formation among blood and oral isolates of Candida albicans and Candida dubliniensis. Enferm Infecc Microbiol Clin, Espanha, v. 29, n. 9, p. 660-5, 2011.https://doi.org/ 10.1016/j.eimc.2011.06.009

WILLIAMS D. W., JORDAN R. P., WEI XQ, ALVES C. T., WISE M. P., WILSON M. J. Interactions of Candida albicans with host epithelial surfaces. J Oral Microbiol, Portugal, v. 21, n. 5, p. 1-8, 2013. https://doi.org/ 10.3402/jom.v5i0.22434

ZAMPERINI C. A., MACHADO A. L, VERGANI C. E., PAVARINA A. C., GIAMPAOLO E. T., DA CRUZ N. C. Adherence in vitro of Candida albicans to plasma treated acrylic resin. Effect of plasma parameters, surface roughness and salivary pellicle. Arch Oral Biol, Sorocaba, v. 55, n. 10, p. 763-70, 2010. https://doi.org/10.1016/j.archoralbio.2010.06.015 